\title{
Mild Thermal Pre-treatment as a Method for Increasing the Methane Potential of Food Waste
}

\author{
Farihah Fadzil ${ }^{1,2}$, Farizah Fadzil ${ }^{1,2}$, Siti Mariam Sulaiman ${ }^{1,2}$, A’isyah Mardhiyyah Shaharoshaha $^{1,2}$, Roslinda \\ Seswoya ${ }^{1,2 *}$ \\ ${ }^{1}$ Micro Pollutant Research Centre, Universiti Tun Hussein Onn Malaysia, 86400, Parit Raja, Johor, Malaysia \\ ${ }^{2}$ Faculty of Civil Engineering and Built Environment, Universiti Tun Hussein Onn Malaysia, 86400, Parit Raja, Johor, \\ Malaysia
}

Corresponding Author Email: roslinda@uthm.edu.my

https://doi.org/10.18280/ijdne.150316

Received: 20 April 2020

Accepted: 7 May 2020

\section{Keywords:}

anaerobic, food waste, Gompertz, mesophilic, thermal

\begin{abstract}
It is challenging to manage the organic fraction of municipal solid waste (OFMSW) because it is putrescible. OFMSW is dominated by food waste, and food waste is easily degradable and causes unpleasant odor at the landfill. Anaerobic digestion was preferable for food waste stabilization. However, the methane production of food waste was low. This research aims to analyze the methane yield and its kinetics from the digestion of thermally treated food waste. In preparing the thermally treated food waste, the water bath at $50^{\circ} \mathrm{C}$ was used and operated for two hours. The biochemical methane potential (BMP) was conducted in a batch reactor. The reactor was operated at a mesophilic temperature at inoculum to substrate ratio of 2.0. The results showed that the ultimate methane yield of thermally treated food waste increased with $630 \mathrm{~mL} \mathrm{CH}_{4} / \mathrm{g}$ VS higher than untreated food waste. The thermal pre-treatment improved the methane production rate with an increment of $9.8 \%$. Besides, kinetic parameters observed from Modified Gompertz modeling were found lesser than laboratory observation. Despite that, thermal pre-treatment at $50^{\circ} \mathrm{C}$ significantly improved the digestion of food waste.
\end{abstract}

\section{INTRODUCTION}

Annually, over 1300 million tonnes of solid waste generated worldwide, and this amount is projected to be increased twofold with an estimation of $46 \%$ organic contents by 2025 [1]. According to Campuzano et al. [2] in North America, OFMSW is a mixture of food, garden waste, and paper waste. OFMSW in Malaysia included food waste, yard waste, containers and packaging, durable and non-durable goods, and various inorganic wastes [3]. Various components and production of OFMSW are mostly influenced by the population and their lifestyle, climate, and geographic area beside the waste management system [4].

Anaerobic digestion does not pollute the environment as the by-product can be transformed into something that can be benefited compared to traditional waste treatment methods [2]. According to Svensson et al. [5], Li et al. [6] and Fan et al. [7], the end product of anaerobic digestion process which is methane gas can be used as renewable energy and the digestate produced can be utilized for agricultural purposed. There are four stages in the anaerobic digestion processes, including hydrolysis, acidogenesis, acetogenesis, and methanogenesis. Different microorganisms with different capabilities worked on digesting organic waste at each step [8].

To improved methane production, the utilization of pretreatment was applied before the anaerobic digestion process. Pre-treatment is a method to enhance the substrate characteristics, subsequently improves the methane yield from the anaerobic digestion [9]. Pre-treatment can be done either by mechanical, thermal, chemical, biological, or combined methods [7]. Nevertheless, each pre-treatment method may result differently depends on the technique itself, and the features of the substrate used [10].

Thermal pre-treatment is the simplest and most researched method that has already been implemented incompletely [11]. According to Wang et al. [12], thermal pre-treatment is recognized as an assuring technique for improving the characteristics of food waste due to the solubilization of organic particles and the promotion of methane production. It has been demonstrated that thermal pre-treatment produces more biogas than untreated food waste. Temperature is a crucial component of enhancing biogas manufacturing in thermal pre-treatment. Mild temperatures can achieve higher solubilization but need more prolonged treatment times. However, because of the creation of complicated polymers such as melanoidins, too elevated temperatures will slow the manufacturing of biogas [11]. According to Ariunbaatar et al. [13], approximately $200 \mathrm{ml} \mathrm{CH}_{4} / \mathrm{g} \mathrm{VS}$ differed in ultimate methane yield between untreated FW and thermally treated $\mathrm{FW}$ at $50^{\circ} \mathrm{C}$. Higher methane yield from thermally treated food waste is due to the faster degradation of the organic particles [14].

Anaerobic digestion of thermally treated food waste improved the characteristics of food waste, which eventually increased the methane yield and methane production [15]. Gandhi et al. [16] observed that the concentration of protein and carbohydrates after thermal pre-treatment is increasing linearly with temperature. Thermal pre-treatment will result in a higher total solid and volatile solid, as observed by Pagliaccia et al. [17]. According to Jin et al. [18], the thermal 
pre-treatment resulted in a decrease in $\mathrm{pH}$. However, a mild temperature was decreased $\mathrm{pH}$ slightly [16] A mild temperatures of 50 to $90^{\circ} \mathrm{C}$ were recommended $[13,16]$

Kinetics study for anaerobic digestion is a must to predict the performance of digesters necessary for designing appropriate digesters [19]. Kinetic studies have been done to fit the cumulative methane yield data obtained from the anaerobic digestion. Modified Gompertz Model is one of the appropriate methods for estimating the anaerobic digestion biogas and methane production [19]. According to Gandhi et al. [16], the kinetic parameters of the laboratory result shall have a small percentage difference from the Modified Gompertz Model, usually less than $10 \%$ difference.

The study on the impact of thermal pre-treatment on food waste generated in Malaysia is quite limited. Therefore, this study was initiate to obtain a comprehensive understanding of the anaerobic digestion of food waste generated in Malaysia, including the effect of mild thermal pre-treatment on the food waste characteristics, the methane yield, and the methane production kinetics as well.

\section{METHODOLOGY}

\subsection{Substrates}

Food wastes (FW) were directly collected from a cafeteria. Impurities such as plastics and big bones were manually removed from the FW [6]. The FW then was diluted with tap water with ratio food waste: tap water of $1: 2$, respectively, to form food waste slurry [20]. For homogenizing the sample, the kitchen blender is used. The samples were stores in the refrigerator at $4^{\circ} \mathrm{C}$ before the use [21].

\subsection{Inoculum}

The inoculum was taken from the full-scale anaerobic digester treating POME. The sample from the plant was stored in plastic containers and retained at $4^{\circ} \mathrm{C}$ to prevent biodegradation. Before each test, the sludge first needs to be taken out from the refrigerator and remain at room temperature $[22,23]$.

\subsection{Preparation of thermally treated food waste}

The water bath was used for the preparation of thermal pretreated FW. FW was placed inside the beaker and directly placed in the water bath at $50^{\circ} \mathrm{C}$ for 2 hours. After 2 hours, the sample was left to be cold at room temperature before use for the biochemical methane potential test [16].

\subsection{Anaerobic digestion experiment set up and procedure}

Following precedent studies by Li et al. [6], Qin et al. [24], $\mathrm{Yu}$ et al. [25] and Seswoya et al. [26] the batch biochemical methane potential (BMP) test was conducted by Automatic Methane Potential System (AMPTS II) as illustrated in Figure 1. BMP test is done with a triplicate sample reactor and a duplicate reactor. The blank reactor purposely prepared to measure methane production from the inoculum itself [27]. This batch study carried out with $500 \mathrm{ml}$ digester with the total mass of inoculum and substrate of 400gram [28]. The inoculum to substrate (I/S) ratio of 2 was selected [11, 13]. The mass of the substrate and inoculum in the reactor was calculated accordingly to VS (in \%) [26]. Then, the anaerobic environment was created by purging the pure nitrogen gas for two minutes [21]. Consistently, reactors were remained at mesophilic temperature $\left(35 \pm\right.$ two $\left.{ }^{\circ} \mathrm{C}\right)$ and were automatically stirred at $90 \mathrm{rpm}$ for $10 \mathrm{~s}$ every $1 \mathrm{~min}$ [16].

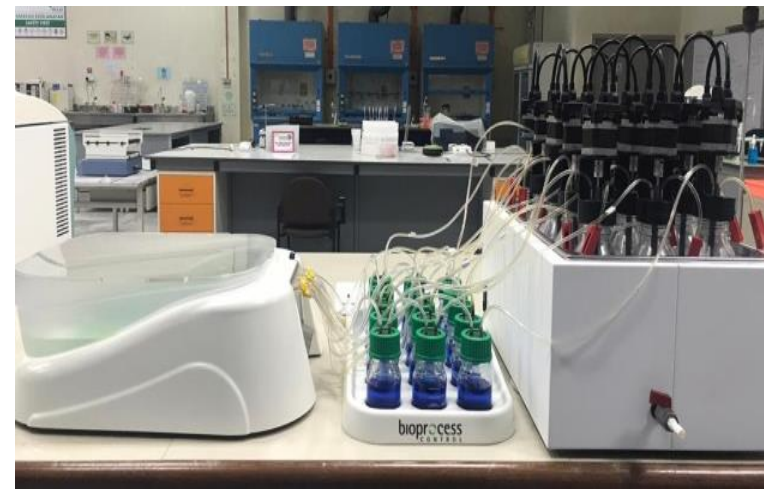

Figure 1. Automatic Methane Potential (AMPTS II)

\subsection{Analytical methods}

The results from the triplicate were reported, referred to as the mean value. The summary of all the experimented methods, as shown in Table 1.

Table 1. The experimental method for the analytical method

\begin{tabular}{ccc}
\hline Parameter & Method of Measurement & Reference \\
\hline $\begin{array}{c}\text { Total Solids (TS) } \\
\text { Volatile Solids } \\
\text { (VS) }\end{array}$ & Section 2540G (APHA 2005) & {$[13]$} \\
pH & Section 2540G (APHA 2005 & {$[13]$} \\
Alkalinity & Standard method 2320B by APHA & {$[29]$} \\
$\begin{array}{c}\text { Chemical } \\
\text { Oxygen Demand Hach }\end{array}$ \\
$\begin{array}{c}\text { (COD) } \\
\text { Carbohydrate } \\
\text { Protein }\end{array}$ & Phenol Sulphuric Acid Method & {$[21]$} \\
\hline
\end{tabular}

\subsection{Modified Gompertz Model}

The Modified Gompertz modeling (Eq. (1)) was adopted to describe the kinetics of methane production over anaerobic digestion test [16].

$$
M=M_{o} \cdot \operatorname{ex} 1 p\left\{-\exp \left[\frac{R m \cdot e}{M_{o}}(\lambda-\mathrm{t})+1\right]\right\}
$$

where,

$\mathrm{M}=$ the cumulative methane yield at time $\mathrm{t}(\mathrm{mL} / \mathrm{g} \mathrm{VS}$ added)

$M_{\mathrm{o}}=$ the methane potential maximum production (mL/g VS added) d)

$\mathrm{Rmax}=$ the maximum methane production rate $(\mathrm{mL} / \mathrm{g} \mathrm{VS}$ -

$\lambda=$ lag phase $(\mathrm{d})$

$\mathrm{t}=$ duration of the assay $(\mathrm{d})$

$\mathrm{e}=\exp (1)=2.7183$ 


\section{RESULTS AND DISCUSSIONS}

\subsection{Characteristic of untreated food waste (FW), thermally treated food waste (FW50) and inoculum}

The characteristics of untreated food waste (FW), thermally treated food waste at $50^{\circ} \mathrm{C}(\mathrm{FW} 50)$ and inoculum were tabulated in Table 2. The $\mathrm{pH}$ for FW and FW50 remained in a neutral range of 7.2 and 7.3, respectively. However, Gandhi et al. [16] reported the decreasing $\mathrm{pH}$ upon thermal pre-treatment. Saragih et al. [15] observed almost similar observations. The FW has lower TS and VS concentration compared to FW50. These results are coinciding with data published by Ma et al. [30]. Besides, the alkalinity for FW and FW50 was less than $300 \mathrm{mg} / \mathrm{L}$ as $\mathrm{CaCO}_{3}$. Oliveira et al. [31] also observed alkalinity lesser than $300 \mathrm{mg} / \mathrm{L}$ as $\mathrm{CaCO}_{3}$ from food waste. This study recorded total chemical oxygen demand (TCOD) of FW50 higher compared to FW, which is corresponding with reported by Seyed Abbas et al. [32]. Ding et al. [33] also found the significant effects of thermal pre-treatment, particularly on TS, VS, and TCOD. However, the FW and FW50 contain a higher concentration of carbohydrates compare to the protein content. Ariunbaatar et al. [11] also observed the similarities.

The inoculum used is active anaerobic biomass originates from a full-scale anaerobic digester. It contained all the required microbes necessary for the anaerobic digestion process. The inoculum used in this study has a $\mathrm{pH}$ of 8.7 . According to De Vrieze et al. [34], inoculum taken full-scale digester has various $\mathrm{pH}$, ranging from 8.0 to 9.0. Chen et al. [35] stated that the alkalinity of inoculum from the full-scale digester is $980 \pm 50 \mathrm{mg} / \mathrm{l}$ as $\mathrm{CaCO}_{3}$, which is higher than inoculum used in this study which was only $758.33 \pm 11.79$ $\mathrm{mg} / \mathrm{l}$ as $\mathrm{CaCO}_{3}$. Protein content in the inoculum is higher than the carbohydrate content, and this is similar to the result from Ariunbaatar et al. [11]. The VS/TS of the inoculum used in this study is 0.53 . Other researchers reported that the inoculum from a full-scale anaerobic digester having VS/TS of 0.47 to $0.63[13,36]$.

Table 2. Characteristics of FW, FW50, and inoculum (N=3)

\begin{tabular}{cccc}
\hline Characteristics & FW & FW50 & Inoculum \\
\hline $\mathrm{pH}$ & 7.2 & 7.3 & 8.7 \\
Total Solid (TS) $(\mathrm{g} / \mathrm{l})$ & $198.5 \pm$ & $200.9 \pm$ & $20.8 \pm 1.5$ \\
& 6.4 & 7.5 & \\
Volatile Solid (VS) $(\mathrm{g} / \mathrm{l})$ & $144.0 \pm$ & $199.9 \pm$ & $11.1 \pm 1.1$ \\
Total Alkalinity & 257.3 & 53.4 & \\
(mgCaCO $/ 1)$ & 117.9 & $250.0 \pm$ & $758.3 \pm$ \\
Total Chemical Oxygen & $1399 \pm$ & $1653.3 \pm$ & 11.8 \\
Demand (g/l) & 3.6 & 1.5 & 798.0 \\
Total Carbohydrate $(\mathrm{g} / \mathrm{l})$ & $277.2 \pm$ & $277.9 \pm$ & $279.7 \pm$ \\
& 0.1 & 0.1 & 0.1 \\
Total Protein $(\mathrm{g} / \mathrm{l})$ & $114.3 \pm$ & $114.0 \pm$ & $94.9 \pm 0.1$ \\
\hline
\end{tabular}

\subsection{Methane accumulation}

The net methane accumulations were determined by the result from the subtracting of methane accumulation of the sample reactor and the blank reactor. The blank reactor was done during the BMP test is to act as a controlled subject in which the product will be represented as the volume of methane production solely from the inoculum individually
[13]. Figures 2(a) and 2(b) illustrated the methane accumulation of FW and FW50, respectively. The net methane accumulation of $610.8 \mathrm{~mL}$ was observed from FW starting from day 15 . Meanwhile, the $676.1 \mathrm{~mL}$ of pure methane was seen from FW50 starting from day 17.

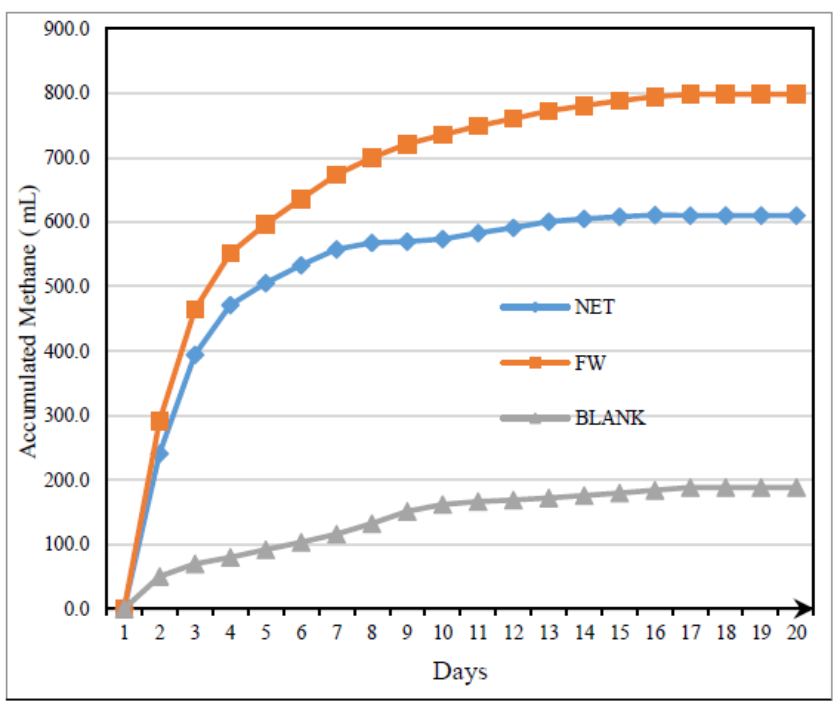

(a) FW

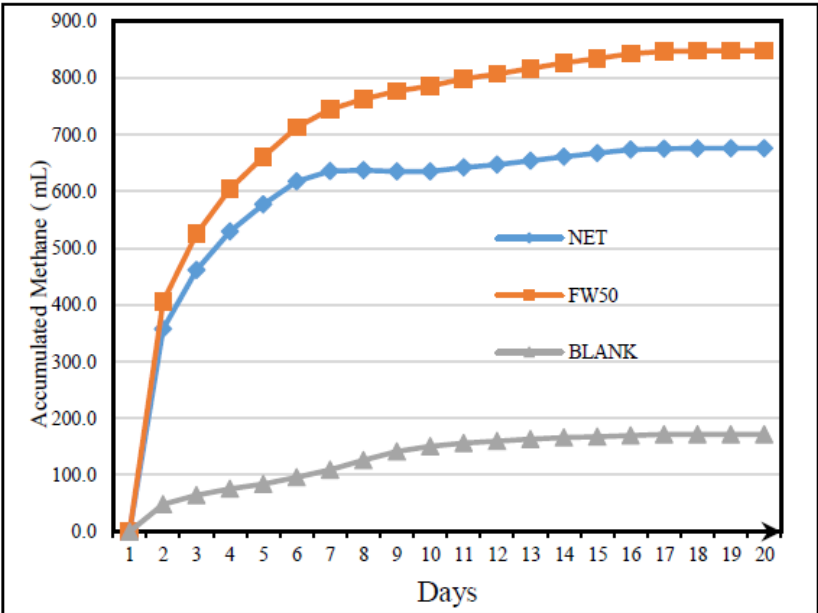

(b) FW50

Figure 2. Methane accumulation graph for 20 days

\subsection{Ultimate methane yield}

The methane yield observed from FW, and FW50 digestion was shown in Table 3, respectively. From the calculation, the ultimate methane yield for FW and FW50 was 1033.6 $\mathrm{mLCH}_{4} / \mathrm{gVS}$ and $1657.8 \mathrm{mLCH}_{4} / \mathrm{gVS}$, respectively. Previous researchers found the ultimate methane yield for $\mathrm{FW}$ and FW50 falls in the range of $200-900 \mathrm{mLCH}_{4} / \mathrm{gVS}$ and 350$1200 \mathrm{mLCH}_{4} / \mathrm{gVS}$, respectively [13, 16, 34, 37]. However, Seswoya et al. [26] showed that the ultimate methane yield for $\mathrm{FW}$ was exceeded $1000 \mathrm{CH}_{4} / \mathrm{gVS}$. The type of inoculum used and the different food waste feed were factors affecting the methane yield [38]. Ariunbaatar et al. [13] showed the difference of ultimate methane yield between FW and FW50 was approximate $200 \mathrm{mLCH}_{4} / \mathrm{gVS}$. Meanwhile, in this study, the difference between the ultimate methane yield between FW and FW50 was $624.2 \mathrm{mLCH}_{4} / \mathrm{gVS}$. Besides, Gandhi et al. [16] found that the ultimate methane yield for FW50 was higher as compared to FW. 
Table 3. Methane yield of FW and FW5 ( $\left.\mathrm{mLCH}_{4} / \mathrm{gVS}\right)$

\begin{tabular}{ccc|ccc}
\hline Days & FW & FW50 & Days & FW & FW50 \\
\hline 0 & 0.0 & 0.0 & 11 & 1002.4 & 1604.9 \\
1 & 408.5 & 452.8 & 12 & 1018.2 & 1620.3 \\
2 & 668.2 & 836.1 & 13 & 1025.3 & 1634.1 \\
3 & 799.0 & 1088.9 & 14 & 1031.4 & 1646.6 \\
4 & 855.9 & 1268.8 & 15 & 1035.3 & 1656.4 \\
5 & 903.5 & 1426.8 & 16 & 1033.9 & 1657.8 \\
6 & 945.2 & 1511.6 & 17 & 1033.6 & 1657.8 \\
7 & 962.3 & 1544.3 & 18 & 1033.6 & 1657.8 \\
8 & 965.8 & 1563.7 & 19 & 1033.6 & 1657.8 \\
9 & 971.8 & 1579.7 & 20 & 1033.6 & 1657.8 \\
10 & 987.6 & 1594.1 & & & \\
\hline
\end{tabular}

\subsection{Modified Gompertz Model (GM)}

Table 4 summarized the kinetics parameter from the digestion of FW and FW50. The values of the kinetics parameters from modeling are less than what was calculated from laboratory work, found from the digestion of FW and FW50, respectively. The percentage difference of ultimate methane yield between laboratory results and modeling results is around 4\%. Gandhi et al. [16] also observed about 6\% difference between laboratory results and modeling results. In contrast, the kinetics parameters from modeling for FW50 were higher than FW. However, as expected, the ultimate methane yield and methane production rate were improved significantly due to the thermal pre-treatment at $50^{\circ} \mathrm{C}$. The methane production rate from laboratory work for $\mathrm{FW}$ and FW50 is $408.475 \mathrm{mLCH}_{4} / \mathrm{VS} /$ day and 452.759 $\mathrm{mLCH}_{4} / \mathrm{VS} /$ day, respectively. The improved methane production rate for FW50 was due to the higher presence of soluble organic as a result of the thermal pretreatment [16].

Table 4. Kinetic parameter for digestion of FW and FW50

\begin{tabular}{ccccc}
\hline $\begin{array}{c}\text { Kinetic } \\
\text { parameters }\end{array}$ & \multicolumn{2}{c}{ Laboratory } & \multicolumn{2}{c}{$\begin{array}{c}\text { Modified } \\
\text { Gompertz }\end{array}$} \\
\hline Sample & FW & FW50 & FW & FW50 \\
\hline $\begin{array}{c}\text { Ultimate } \\
\text { methane yield } \\
\text { (mLCH4/gVS) } \\
\begin{array}{c}\text { Methane } \\
\text { production rate } \\
\text { (mLCH4/gVS/d) }\end{array}\end{array}$ & 1033.64 & 1657.84 & 993.40 & 1616.46 \\
$\boldsymbol{\lambda}($ day) & 0.08 .47 & 452.76 & 361.63 & 410.13 \\
\hline
\end{tabular}

\section{CONCLUSIONS}

Thermally pre-treatment at $50^{\circ} \mathrm{C}$ improved the food waste characteristics particulars on solids and chemical oxygen demand (COD). Subsequently, it showed better biodegradability. The sludge from a full-scale anaerobic digester treating POME had similarities with other sludges taken from a full-scale anaerobic digester. From the BMP assay, the net methane accumulation, methane production rate, and ultimate methane yield for FW50 were recorded higher from the FW as expected. The lag phase smaller than one day indicated that there was no acclimatization period. The ultimate methane yield for FW and FW50 exceeded $1000 \mathrm{~mL}$ $\mathrm{CH}_{4} / \mathrm{gVS}$. However, the ultimate methane yield for FW50 was higher than FW with a difference of $624.2 \mathrm{mLCH}_{4} / \mathrm{gVS}$. The kinetic parameters for both FW and FW50 obtained from Modified Gompertz modeling were lesser as compared to the laboratory observation.

\section{ACKNOWLEDGMENT}

The authors wished to thank Cenergi SEA Sdn. Bhd for their cooperation to make this study possible and Universiti Tun Hussein Onn Malaysia for the financial support through GPPS-H565, and MDR Grant-H489.

\section{REFERENCES}

[1] Seadi, T., Lukehurst, C. (2012). Quality management of digestate from biogas plants used as fertiliser. IEA Bioenergy.

[2] Campuzano, R., González-Martínez, S. (2016). Characteristics of the organic fraction of municipal solid waste and methane production: A review. Waste Management, 54: 3-12. https://doi.org/10.1016/j.wasman.2016.05.016

[3] Tarmudi, Z., Abdullah, M.T.A. (2012). A review of municipal solid waste management in Malaysia. Jurnal Teknologi, $\quad 57$ : 41-56. http://dx.doi.org/10.11113/jt.v57.1252

[4] Hansen, T.L., Jansen, J.C., Davidsson, Å., Christensen, T.H. (2007). Effects of pre-treatment technologies on quantity and quality of source-sorted municipal organic waste for biogas recovery. Waste Management, 27(3): 398-405. https://doi.org/10.1016/j.wasman.2006.02.014

[5] Svensson, K., Kjørlaug, O., Higgins, M.J., Linjordet, R., Horn, S.J. (2018). Post-anaerobic digestion thermal hydrolysis of sewage sludge and food waste: Effect on methane yields, dewaterability and solids. Water Research, 132 : 158-166. https://doi.org/10.1016/j.watres.2018.01.008

[6] Li, Y., Jin, Y., Borrion, A., Li, J. (2018). Kinetic studies on organic degradation and its impacts on improving methane production during anaerobic digestion of food waste. Applied Energy, 213: 136-147. https://doi.org/10.1016/j.apenergy.2018.01.033

[7] Fan, Y.V., Tin, C., Perry, S. (2018). Anaerobic digestion of municipal solid waste: Energy and carbon emission footprint. Journal of Environmental Management, 223: 888-897. https://doi.org/10.1016/j.jenvman.2018.07.005

[8] Ivanovs, K., Spalvins, K., Blumberga, D. (2018). Approach for modelling anaerobic digestion processes of fish waste. Energy Procedia, 147: 390-396. https://doi.org/10.1016/j.egypro.2018.07.108

[9] Cesaro, A., Belgiorno, V. (2014). Pre-treatment methods to improve anaerobic biodegradability of organic municipal solid waste fractions. Chemical Engineering Journal, 240:

24-37. https://doi.org/10.1016/j.cej.2013.11.055

[10] Ariunbaatar, J., Panico, A., Esposito, G., Pirozzi, F., Lens, P.N.L. (2014). Pre-treatment methods to enhance anaerobic digestion of organic solid waste. Applied Energy, 123: 143-156. https://doi.org/10.1016/j.apenergy.2014.02.035

[11] Ariunbaatar, J., Panico, A., Frunzo, L., Esposito, G., Lens, P.N.L., Pirozzi, F. (2014). Enhanced anaerobic digestion of food waste by thermal and ozonation pretreatment methods. Journal of Environmental Management, $\quad 146$ : 142-149. 
https://doi.org/10.1016/j.jenvman.2014.07.042

[12] Wang, W., Hou, H., Hu, S., Gao, X. (2010). Performance and stability improvements in. anaerobic digestion of thermally hydrolyzed municipal biowaste by a biofilm system. Bioresource Technology, 101(6): 1715-1721. https://doi.org/10.1016/j.biortech.2009.10.010

[13] Ariunbaatar, J., Panico, A., Yeh, D.H., Pirozzi, F., Lens, P.N.L., Esposito, G. (2015). Enhanced mesophilic anaerobic digestion of food waste by thermal pretreatment: Substrate versus digestate heating. Waste Management, 46: 176-181. https://doi.org/10.1016/j.wasman.2015.07.045

[14] Li, Y., Jin, Y., Li, J., Li, H., Yu, Z. (2016). Effects of thermal pre-treatment on the biomethane yield and hydrolysis rate of kitchen waste. Applied Energy, 172(1020): 47-58. https://doi.org/10.1016/j.apenergy.2016.03.080

[15] Saragih, F.N.A., Priadi, C.R., Adityosulindro, S., Abdillah, A., Islami, B.B. (2019). The effectiveness of anaerobic digestion process by thermal pre- treatment on food waste as a substrate. IOP Conference Series: Earth and Enviromental Science, 251: 012014. https://doi.org/10.1088/1755-1315/251/1/012014

[16] Gandhi, P., Paritosh, K., Pareek, N., Mathur, S., Lizasoain, J., Gronauer, A., Bauer, A., Vivekanand, V. (2018). Multicriteria decision model and thermal pretreatment of hotel food waste for robust output to biogas: Case study from city of Jaipur, India. BioMed Research International, https://doi.org/10.1155/2018/9416249

[17] Pagliaccia, P., Gallipoli, A., Gianico, A., Gironi, F., Montecchio, D., Pastore, C., Braguglia, C.M. (2019). Variability of food waste chemical composition: Impact of thermal pre-treatment on lignocellulosic matrix and anaerobic biodegradability. Journal of Environmental Management, 236: 100-107. https://doi.org/10.1016/j.jenvman.2019.01.084

[18] Jin, Y., Li, Y., Li, J. (2016). Influence of thermal pretreatment on physical and chemical properties of kitchen waste and the efficiency of anaerobic digestion. Journal of Environmental Management, 180: 291-300. https://doi.org/10.1016/j.jenvman.2016.05.047

[19] Deepanraj, B., Sivasubramanian, V., Jayaraj, S. (2017). Science direct effect of substrate pre-treatment on biogas production through anaerobic digestion of food waste. International Journal of Hydrogen Energy, 42(42): 26522-26528. https://doi.org/10.1016/j.ijhydene.2017.06.178

[20] Lou, X.F., Nair, J., Ho, G. (2012). Effects of volumetric dilution on anaerobic digestion of food waste. Journal of Renewable and Sustainable Energy, 4(6): 1-11. https://doi.org/10.1063/1.4764935

[21] Cabbai, V., Ballico, M., Aneggi, E., Goi, D. (2013). BMP tests of source selected OFMSW to evaluate anaerobic codigestion with sewage sludge. Waste Management, 33(7): https://doi.org/10.1016/j.wasman.2013.03.020

[22] Silva, F.M.S., Mahler, C.F., Oliveira, L.B., Bassin, J.P. (2018). Hydrogen and methane production in a two-stage anaerobic digestion system by co-digestion of food waste, sewage sludge and glycerol. Waste Management, 76: 339-349. https://doi.org/10.1016/j.wasman.2018.02.039

[23] Zahedi, S., Rivero, M., Solera, R., Perez, M. (2018). Mesophilic anaerobic co-digestion of sewage sludge with glycerine: Effect of solids retention time. Fuel, 215: 285289. https://doi.org/10.1016/j.fuel.2017.11.007

[24] Qin, Y., Wang, H., Li, X., Cheng, J.J., Wu, W. (2017). Improving methane yield from organic fraction of municipal solid waste (OFMSW) with magnetic ricestraw biochar. Bioresource Technology, 245: 1058-1066. https://doi.org/10.1016/j.biortech.2017.09.047

[25] Yu, M., Zhao, M., Huang, Z., Xi, K., Shi, W., Ruan, W. (2017). A model based on feature objects aided strategy to evaluate the methane generation from food waste by anaerobic digestion. Waste Management, 72: 218-226. https://doi.org/10.1016/j.wasman.2017.10.038

[26] Seswoya, R., Tarmizi, A., Karim, A., Darnak, N.A., Fahmi, M., Rahman, A. (2018). Methane potential from the digestion of food waste in a batch reactor. International Journal of Engineering \&Technology, 7: 36-39. http://dx.doi.org/10.14419/ijet.v7i3.23.17255

[27] Lü, F., Xu, X., Shao, L., He, P. (2015). Importance of storage time in mesophilic anaerobic digestion of food waste. Journal of Environmental Sciences (China), 45: 76-83. https://doi.org/10.1016/j.jes.2015.11.019

[28] Seswoya, R., Tarmizi, A. (2017). Sample biochemical methane potential from the digestion of domestic mixed sewage sludge in batch tests. International Journal on Advanced Science Engineering Information Technology, 4: 431. https://doi.org/10.18517/ijaseit.7.2.2094

[29] Park, N.D., Thring, R.W., Helle, S.S. (2012). Comparison of methane production by co-digesting fruit and vegetable waste with fi rst stage and second stage anaerobic digester sludge from a two stage digester. Water Science and Technology, 65(7): 1252-1258. https://doi.org/10.2166/wst.2012.004

[30] Ma, J., Duong, T.H., Smits, M., Verstraete, W., Carballa, M. (2011). Enhanced bio methanation of kitchen waste by different pre-treatments. Bioresource Technology, 102(2): 592-599. https://doi.org/10.1016/j.biortech.2010.07.122

[31] de Oliveira, L.R.G., Derovil, A., Filho, S., Vasconcelos, K.C., de Lucena, T.V., Jucá, J.F.T., Santos, A.F.D.M.S. (2018). Methanization potential of anaerobic biodigestion of solid food waste de resíduos sólidos alimentares. Revista Brasileira de Engenharia Agrícola e Ambiental, 22(1): 69-73. https://doi.org/10.1590/18071929/agriambi.v22n1p69-73

[32] Seyed Abbas, R., Hossein Haji Agha, A., Rahman, S. (2018). Enhancement anaerobic digestion and methane production from kitchen waste by thermal and thermochemical pre-treatments in batch leach bed reactor with down flow. Research in Agricultural Engineering, 64(3): 128-135. https://doi.org/10.17221/16/2017-rae

[33] Ding, L., Cheng, J., Qiao, D., Yue, L., Li, Y.Y., Zhou, J., Cen, K. (2017). Investigating hydrothermal pretreatment of food waste for two-stage fermentative hydrogen and methane co-production. Bioresource Technology, 241: 491-499. https://doi.org/10.1016/j.biortech.2017.05.114

[34] De Vrieze, J., Raport, L., Willems, B., Verbrugge, S., Volcke, E., Meers, E., Angenent, L., Boon, N. (2015). Inoculum selection influences the biochemical methane potential of agro-industrial substrates. Microbial Biotechnology, 8(5): 776-786. https://doi.org/10.1111/1751-7915.12268

[35] Chen, S., Zhang, J., Wang, X. (2015). Effects of alkalinity sources on the stability of anaerobic digestion 
from food waste. Waste Management and Research, 33(11): 1033-1040. https://doi.org/10.1177/0734242X15602965

[36] Rafieenia, R., Pivato, A., Lavagnolo, M.C. (2018). Effect of inoculum pre-treatment on mesophilic hydrogen and methane production from food waste using two-stage anaerobic digestion. International Journal of Hydrogen Energy, 43(27):

12013-12022. https://doi.org/10.1016/j.ijhydene.2018.04.170

[37] Park, S., Han, S.K., Song, E., Kim, H., Kim, M., Lee, W.
(2020). Effect of hydrothermal pre-treatment on physical properties and co-digestion from food waste and sewage sludge mixture. Waste Management and Research, 38(5): 546-553. https://doi.org/10.1177/0734242X19897123

[38] Elbeshbishy, E., Nakhla, G., Hafez, H. (2012). Biochemical methane potential (BMP) of food waste and primary sludge: Influence of inoculum pre-incubation and inoculum source. Bioresource Technology, 110: 1825. https://doi.org/10.1016/j.biortech.2012.01.025 